\title{
The Functional Positioning and Implementation Path of College Chinese in Higher Vocational Colleges Based on Liberal Education
}

\author{
Shuhong Sun \\ Changchun Vocational Institute of Technology, Changchun, China \\ sunshuhongcc@126.com
}

Keywords: liberal education; higher vocational colleges; college Chinese; functional positioning

Abstract: In the higher vocational college education system, college Chinese has always been in an awkward position. Under the new situation of reforming higher vocational education vigorously, how to position college Chinese and how to adapt to the needs of the development of higher vocational and technical talents has become very essential for the current reform of college Chinese in higher vocational colleges. In this paper, the author analyzes how to position college Chinese in higher vocational colleges and puts forward reform strategies, in the hope of offering some help to enhance the teaching effect of college Chinese in higher vocational colleges.

\section{Introduction}

As an integral part of education, liberal education adheres to the educational concept of "complete man" desired by the society and provides a new opportunity for the current reform and development of college Chinese education. As an important course of liberal education, college Chinese in higher vocational colleges is a course in a particular position. It focuses on cultivating students' humanistic qualities and the depth and thickness of their knowledge, strengthens reading, writing and speaking skills and highlights the practical value of rational thinking. However, from the status quo of current higher vocational education, too much emphasis is laid on the training of vocational skills. The harmonious development of students' mind and body is ignored. Much stress is laid on cultivating practical and technical talents. Therefore, it is an indisputable fact that the position of college Chinese has showed a downward trend in higher vocational colleges. In the face of such an awkward situation and the variability of education objects, etc., in view of the demand of the current society for talents, only by repositioning the function of college Chinese teaching, carrying out a teaching reform actively and assuming a right attitude towards problems with college Chinese reform, according to the actual situation of students, can higher vocational colleges give play to the practical function of college Chinese and achieve the goal of liberal education in college Chinese education. 


\section{The Functional Positioning of College Chinese in Higher Vocational Colleges}

The teaching syllabus of higher vocational Chinese course describes the nature of higher vocational Chinese as follows: "Chinese is an important fundamental course in higher vocational education. It is of great significance for students to learn other subjects well, inspire thinking, broaden horizon, improve ideological, moral, cultural and scientific qualities and adapt to the needs of future positions ${ }^{[1]}$. Also, it is vital for the promotion of excellent national cultural heritages and the strengthening of the construction of socialist spiritual civilization.” The syllabus has positioned the nature of higher vocational Chinese very clearly.

\subsection{Instrumental method}

The main task of higher vocational education is to cultivate practical operative and managerial personnel in the frontline of production. As an integral part of higher vocational specialized curriculum system, Chinese teaching must strengthen the practical training of all kinds of abilities to be adapted to future positions, in order to reflect the instrumentality of Chinese teaching in higher vocational colleges. The Chinese abilities should be embodied in being articulate, eloquent and good at writing. The training of the above abilities should be the main theme of college Chinese teaching in higher vocational colleges. The ultimate goal of college Chinese teaching in higher vocational colleges is to cultivate students' comprehensive Chinese application ability. This kind of application ability is mainly reflected in oral expression and written expression. Times calls for talents. At present, the talents needed by the country are not only knowledge-oriented talents, but also application-oriented, skill-oriented, management-oriented and service-oriented talents. This requires our students not only to master good practical abilities, but also to have strong speaking and writing skills. The instrumental positioning of college Chinese may enhance students' professional knowledge and basic skills and adapt to the needs of the new era for higher vocational talents $^{[2]}$.

\subsection{Humanistic factors}

Professional education is employment-oriented education and stresses the training of vocational ability. However, in teaching practice, some higher vocational colleges are biased in their understanding of vocational ability. They simply interpret vocational ability as vocational skills and ignore humanistic factors in them. As a humanistic course, college Chinese in higher vocational colleges should occupy an important position in higher vocational curriculum system. We must guide students to feel the author's noble morality and profound thinking, facilitate the formation of their healthy personality and excellent qualities; pay attention to students' all-round and sustainable development and cultivate their vocational accomplishment, to make the Chinese knowledge they learn helpful to their career development. College Chinese textbooks include excellent ancient, modern, domestic and foreign literary works and condense rich ideological and cultural content. College Chinese should play a role in training students' vocational values, vocational ideal and innovation ability, building a harmonious social relationship, guiding and helping them absorb the quintessence of wisdom and nutrients of spirit correctly, setting up a correct outlook on world, life and values and making them into people with lofty sentiments, coordinated development of body and mind and strong humanistic feelings.

\subsection{Fundamental course}

The role of college Chinese as a fundamental course of humanistic education is determined by its 
linguistic and literary characteristics. It is self-evident that the history and emotion of a nation is implied in its mother tongue and implied in the literary form of its mother tongue. It spreads humanistic education in the most sensible and acceptable form. Both language and literature are social and change with the development of the society. Therefore, what we learn through Chinese is not only ancient historical knowledge and national feelings, but also a realistic understanding of the current social development and emotional world. Compared with other subjects, college Chinese is the most prominent and crucial in the inheritance of culture ${ }^{[3]}$. The culture it disseminates and imparts is of great variety and universality. It must be a fundamental quality education course for college students and in content setting, impart systematic and large-capacity Chinese knowledge. In goal setting, reading stresses appreciation and analysis, expression stresses hands-on practice, while thinking stresses openness and diversity.

\section{The Important Path for College Chinese in Higher Vocational Colleges to Realize Liberal Education}

\subsection{To clarify the positioning of college Chinese in higher vocational colleges}

Compared with ordinary universities, the campus culture and teaching environment in higher vocational colleges are particular. Therefore, higher vocational college students pay more attention to their majors. So college Chinese opened by higher vocational colleges should also be based on the characteristics of their majors and help promote students' vocational accomplishment. The combination between college Chinese teaching and the characteristics of the majors actually requires colleges to focus on students' knowledge demands. The teaching content should adapt to the development of times. If college Chinese course was combined with students' professional knowledge, then two problems, the function of college and the function of college Chinese could be solved $^{[4]}$. Only by putting "studying for the purpose of application" and "teaching students in accordance of their aptitude” into practice can college Chinese play a greater role.

\subsection{To establish a teaching concept of "humanistic edification” in college Chinese}

People's understanding of college Chinese is merely to strengthen the construction of Chinese course, by strengthening students' application and practical use. To change this situation, in actual teaching process, Chinese teachers need to probe in to the higher vocational Chinese course and the particularity of higher vocational students carefully, combine the training goal and social demand of higher vocational education, further clarify the teaching goal, arrange teaching content scientifically and reasonably and put the improvement of students' ability to use Chinese knowledge in the first place, thus establishing an ability-oriented educational view, based on humanity, life, personality and humanism

\subsection{To use "exploratory" teaching form to cultivate students’ thinking ability}

In teaching practice, we can adopt case study, group discussion, situational simulation, role play, classroom demonstration and heuristics, etc., , according to the needs of students in different majors for humanistic knowledge, launch activities, such as oral examination, speech, scene play, narration of writers' works, literature club and courseware presentation, etc., to strengthen the cultivation of students' knowledge transfer ability, guide students to elucidate their own views and opinions clearly, emphasize and reinforce students' language ability, prevent students' thinking from being affected by the original knowledge, experience, attitude, evaluation and traditional concept and train students' divergent thinking and reverse thinking ${ }^{[5]}$. 


\subsection{To refine the assessment mechanism}

The assessment system has an equal status as teaching process in teaching activities and directly influences the realization of teaching goals. It is necessary to change the traditional assessment model which determines students' academic performance simply by students' ordinary grade and final exam result, but turn to focus on their learning process. The whole process of course learning is also a process of assessment. We should test students' comprehensive quality and ability in an all-round way, combine process assessment with summative assessment, implement a teaching and examination model with "itemized teaching", "itemized assessment" and "itemized scoring”, divide teaching content and tasks into sections and items and set ultimate teaching goals to be achieved.

\section{Conclusions}

College Chinese is not an ordinary course, but a course with special mission and responsibility. At a macro level, it involves the development of national culture, the construction of a national spiritual home and the improvement of social citizens' native language ability. At a micro level, it involves the core competitiveness and career development of each higher vocational student. In the current background in which the country vigorously develops excellent traditional culture, college Chinese teaching in higher vocational colleges must assume a "destroying the old and establishing the new" attitude, fully explore and exert the value and function of excellent traditional culture and make due contributions to the cultivation of high-quality technology-based talents.

\section{References}

[1] Hou Jiahua, Reflection on the Reform of Higher Vocational Chinese Teaching from the Perspective of "Micro-course" [J] China Adult Education, 2015(17):156-158.

[2] Xiong Jiahong, "Probe on College Chinese Teaching in Higher Vocational Colleges in the View of Internet Plus Era" [J] Journal of Tianjin R \& TV University. 2016, 20(4):62 -65.

[3] Zhou Xiaoyin, Exploration on Chinese Language Teaching in Higher Vocational Colleges in View of Local Culture [J], Journal of Zhejiang Shuren University (Humanities and Social Sciences), 2016, 16(4):104-108.

[4] Lai Min, On the Innovation Path of Chinese Teaching in Higher Vocational Education Based on the Vocational Ability Orientation [J] Journal of Juamjusi Education Institute, 2016(11):40.

[5] Le Shaohua, Higher Vocational Chinese Teaching should Pay Attention to the Cultivation of Students' Humanistic Quality [J], Journal of Hubei Correspondence University, 2016(21):14-15. 